\title{
Use of FAME from selected vegetable oils and proper evaluation of their content in diesel fuel
}

\begin{abstract}
This article describes the study to determine the effect of FAME from different vegetable oils on the correctness of determination of FAME content in diesel fuel according to PN-EN 14078. It presents the study of the soybean oil, palm and coconut FAME model blends made from esters with different hydrocarbon chain lengths and real FAME samples of soybean, palm and coconut oil. As part of this work there was prepared a calibration curve, dedicated to determining the content of coconut oil FAME. Results of tests and the impact of applied above FAME on results of the FAME determination in diesel fuel were discussed.
\end{abstract}

Key words: coconut oil FAME, palm oil FAME, soybean oil FAME, infrared spectrometry, FAME content determination.

\section{Zastosowanie FAME z wybranych olejów roślinnych, a prawidłowa ocena ich zawartości w oleju napędowym}

\begin{abstract}
Niniejszy artykuł opisuje badania mające na celu określenie wpływu zastosowania FAME wytwarzanych z różnych olejów roślinnych na prawidłowość oznaczenia zawartości FAME w oleju napędowym według PN-EN 14078. Badaniom zostały poddane mieszaniny modelowe FAME oleju sojowego, palmowego oraz kokosowego sporządzonych z estrów o różnych długościach łańcuchów węglowodorowych oraz rzeczywistych próbek FAME oleju sojowego, palmowego i kokosowego. W ramach prowadzonych prac została sporządzona krzywa kalibracyjna, dedykowana do oznaczania zawartości FAME oleju kokosowego. Dokonano omówienia otrzymanych wyników badań oraz wpływu pochodzenia zastosowanego FAME na wyniki oznaczenia jego zawartości w oleju napędowym.
\end{abstract}

Słowa kluczowe: FAME oleju kokosowego, FAME oleju palmowego, FAME oleju sojowego, spektrometria w podczerwieni, oznaczanie zawartości FAME.

\section{Introduction}

The production of fatty acid methyl esters (FAMEs) in Poland is mainly based on transesterification of a rapeseed oil obtained from the rapeseed cultivated in Poland. As a product of domestic origin, it stimulates the development of the local biofuel production market but the presence of fatty acid methyl esters from other vegetable oils has been clearly increasing in recent years. The increase in the diversity of the origin of FAMEs as a diesel fuel component testifies to the diversification of the supply but it does have an impact on the spectrum of conducted testing. The Oil and Gas Institute - National Research Institute has been investigating properties of FAMEs from various sources for propulsion and heating purposes for many years [1-4]. Therefore, it seems justified to determine the influence of the type of FAMEs on the correctness of their content determination as a fuel additive.
The content of fatty acid methyl esters (FAMEs) in diesel fuel is one of the obligatory quality parameters of this fuel, which is periodically checked as part of the Polish governmental fuel quality control and monitoring system. Because FAME production in Poland is mainly based on the rapeseed oil transesterification technology, these esters are the basic reference material in laboratories taking part in fuel monitoring. However, FAMEs produced from other vegetable oils are also present on the domestic market. This diversity may influence on the results of tests of the quality of diesel fuel containing such a biocomponent.

The Regulation of the Minister of Economy on methods of testing the quality of liquid fuels [18] refers to the PN-EN 14078 standard [16], which uses infrared spectrometry technique, for the determination of FAME content in diesel fuel. 
The method is based on measuring the absorption of the stretching vibrations of the double bond of carbon-oxygen $(\mathrm{C}=\mathrm{O})$ in the range of $1745 \pm 5 \mathrm{~cm}^{-1}$ in a given sample volume. Thus, the amount of ester bonds contained in the sample is determined without determining the differences in the lengths of FAME hydrocarbon chains. The use of FAME as a diesel additive with a different share of esters with specific hydrocarbon chain lengths may affect the difference between the actual and determined FAME content.

Table 1 shows the composition of fatty acids of selected vegetable oils used for FAME production. Fatty acid methyl esters of rapeseed, soybean and palm oils [13], which have a relatively similar fatty acid composition, have the largest share in the global FAME market. However, FAMEs made from vegetable oils with a higher share of the fatty acids with shorter chains than the fatty acids contained in the three oils mentioned above, such as coconut oil FAMEs, are also available on the market. Therefore, the same volume of FAMEs produced from coconut oil and rapeseed oil will contain a different number of ester bonds.
Table 1. Composition of fatty acids of selected vegetable oils $[6,7,9,14]$

\begin{tabular}{|l|c|c|c|c|}
\hline \multicolumn{1}{|c|}{$\begin{array}{c}\text { Fatty acid content } \\
{[\%(m / m)]}\end{array}$} & \multicolumn{5}{c|}{ Vegetable oil type } \\
\cline { 2 - 5 } rapeseed & soybean & palm & coconut \\
\hline Caproic acid C:6 & - & - & - & $0 \div 0.8$ \\
\hline Caprylic acid C:8 & - & - & - & $5 \div 9$ \\
\hline Capric acid C:10 & - & - & - & $4 \div 10$ \\
\hline Lauric acid C:12 & - & - & - & $44 \div 52$ \\
\hline Myristic acid C: 14 & - & $0 \div 0.3$ & $0.5 \div 6$ & $13 \div 19$ \\
\hline Palmitic acid C:16 & $2 \div 5$ & $7 \div 11$ & $32 \div 47$ & $7 \div 11$ \\
\hline Stearic acid C:18 & $1 \div 2$ & $2 \div 6$ & $1 \div 7$ & $1 \div 4$ \\
\hline Oleic acid C:18:1 & $10 \div 60$ & $22 \div 34$ & $38 \div 52$ & $5 \div 8$ \\
\hline Linoleic acid C:18:2 & $10 \div 21.5$ & $43 \div 60$ & $2 \div 11$ & $1 \div 3$ \\
\hline Linolenic acid C:18:3 & $5 \div 10$ & $2 \div 11$ & - & - \\
\hline Arachidic acid C:20 & - & $5 \div 10$ & - & $0 \div 0.5$ \\
\hline
\end{tabular}

\section{Methods for determining FAME content in diesel fuel}

Standard PN-EN 14078 [18] provides the most common method for testing FAME content in diesel fuel, invoked in the Regulation of the Minister of Economy on methods of testing the quality of liquid fuels [15]. At present, there is no other standardised method allowing the measurement result to be independent of the FAME type used for the production of diesel fuel being the subject of the determination. Standard ASTM D 7371 [17], which uses FTIR-ATR-PLS spectroscopy for FAME determination, does not take into account the differences in the lengths of FAME hydrocarbon chains, either.

Literature also provides other methods for the determination of FAME content, such as by field method [5], the measurement of radioactive carbon $\mathrm{C}_{14}$ [8], X-ray fluorescence technique with energy dispersion [13], UV-VIS spectrometry [11], gas chromatography with detector (O-FID) [2] and magnetic resonance spectroscopy [10]. These are not standardized methods, though.

\section{Scope of works}

As part of the conducted research, model blends of FAMEs of soybean, palm and coconut oils containing fatty acid methyl esters with various hydrocarbon chain lengths $\left(\mathrm{C}_{8}-\mathrm{C}_{20}\right)$ were prepared. The model blends were used to prepare solutions in the base diesel fuel. Next, FAME solutions from the transesterification of soybean, palm and coconut oils were prepared and their FAME contents were determined by infrared spectrometry according to PN-EN 14078 [18]. The tests were performed in the measuring range from $3 \%(V / V)$ to $30 \%(V / V)$ of FAME in diesel fuel. The obtained results were used to determine the susceptibility of the method to a change of a vegetable oil type from which the FAME was produced.

\section{Instruments used}

The determinations were performed on the FT-IR Excalibur spectrometer manufactured by $\mathrm{BIO}-\mathrm{RAD}$ with use of $\mathrm{NaCl}$ measuring cuvettes.
The absorbance values were calculated using calibration curves prepared using the FAME standard for rapeseed oil in accordance with the PN-EN 14078 methodology [18]. 


\section{Fatty acid methyl esters used}

Individual reference methyl esters of various fatty acids manufactured by Sigma-Aldrich, which had a purity $>99 \%$, were used to compose the model FAME blends.

The tests also used commercially available biocomponents of palm and soybean oils.

\section{The analysis of model FAME blends (composed by using individual standard fatty acid methyl esters)}

In the first stage of the work, model FAME blends were prepared for soybean, palm and coconut oils. The percentage shares of methyl esters of the individual fatty acids for soybean and coconut oils were selected in accordance with Table B1 of PN-EN ISO 5509 [19] standard (which provides an example composition of FAMEs with appropriate chain lengths in the products of transesterification of the above-mentioned oils) and for palm oil in accordance with Table 1. The individual shares are shown in Table 2.

The blends were used to prepare weight solutions in the base diesel fuel with the appropriate concentrations. Next, the

Table 2. Model blends of methyl esters of fatty acids of individual vegetable oils

\begin{tabular}{|c|c|c|c|}
\hline \multirow{2}{*}{$\begin{array}{c}\text { Fatty acid } \\
\text { methyl esters }\end{array}$} & \multicolumn{3}{|c|}{$\begin{array}{c}\text { Content of individual esters in the FAMEs } \\
\text { produced from } \\
\end{array}$} \\
\cline { 2 - 4 } & soybean oil $(\mathrm{m} / \mathrm{m})]$ \\
\hline $\mathrm{C}_{8}$ & - & - & 6.8 \\
\hline $\mathrm{C}_{10}$ & - & - & 5.5 \\
\hline $\mathrm{C}_{12}$ & - & - & 47.1 \\
\hline $\mathrm{C}_{14}$ & - & 1.0 & 18.4 \\
\hline $\mathrm{C}_{16}$ & 11.9 & 39.8 & 10.1 \\
\hline $\mathrm{C}_{18}$ & 88.1 & 59.2 & 12.1 \\
\hline $\mathrm{C}_{20}$ & 0.6 & - & 0.1 \\
\hline
\end{tabular}

Table 4. Determination of FAME content according to PN-EN 14078:14 [18] for the solutions of the coconut oil model FAME blend

\begin{tabular}{|c|c|c|}
\hline \multicolumn{2}{|c|}{$\begin{array}{c}\text { FAME content } \\
{[\%(V / V)]}\end{array}$} & $\begin{array}{c}\text { Expanded uncertainty of } \\
\text { the determination result }\end{array}$ \\
$\begin{array}{c}\text { expected (based on } \\
\text { the weight prepara- } \\
\text { tion of the model } \\
\text { blend) }\end{array}$ & $\begin{array}{c}\text { determined } \\
\text { according to } \\
\text { PN-EN } 14078\end{array}$ & $\mathrm{U})=2 \cdot \mathrm{R} / 2.8 \%(V / V)$ \\
\hline 3.0 & 4.0 & 0.2 \\
\hline 6.9 & 9.2 & 0.5 \\
\hline 15.3 & 20.2 & 1.1 \\
\hline 21.7 & 28.4 & 1.3 \\
\hline 33.5 & 44.1 & 2.0 \\
\hline
\end{tabular}

The FAMEs of coconut oil with a $98.8 \%$ purity was obtained through the transesterification of coconut oil according to PN-EN ISO 5509 (general method of preparation dry methyl esters for IR spectroscopy using boron trifluoride) [19].

FAME content was determined in accordance with PN-EN 14078. Results are presented in Tables 3, 4 and 5.

It was found on the basis of the obtained results that the results of FAME determinations for FAME blends of soybean and palm oils, using the calibration curve prepared for the FAMEs of rapeseed oil, do not differ by more than the expanded uncertainty of the method in relation to the expected value. In the case of the results of the FAME determinations for the coconut oil FAME blend, the results were inflated by approx. $30 \%$ in relation to the expected value.

Table 3. Determination of FAME content according to PN-EN 14078:14 [18] for the solutions of the soybean oil model FAME blend

\begin{tabular}{|c|c|c|}
\hline \multicolumn{2}{|c|}{$\begin{array}{c}\text { FAME content } \\
{[\%(V / V)]}\end{array}$} & Expanded uncertainty of \\
the determination result \\
expected (based on \\
$\begin{array}{c}\text { exe weight prepara- } \\
\text { tion of the model } \\
\text { blend) }\end{array}$ & $\begin{array}{c}\text { determined } \\
\text { according to } \\
\text { PN-EN 14078 }\end{array}$ & $\mathrm{U}(\mathrm{R})=2 \cdot \mathrm{R} / 2.8 \%(V / V)$ \\
\hline 3.3 & 3.3 & 0.1 \\
\hline 7.6 & 7.5 & 0.4 \\
\hline 15.6 & 15.6 & 0.9 \\
\hline 20.3 & 20.4 & 1.1 \\
\hline 32.1 & 31.9 & 1.4 \\
\hline
\end{tabular}

Table 5. Determination of FAME content according to PN-EN 14078:14 [18] for the solutions of the palm oil model FAME blend

\begin{tabular}{|c|c|c|}
\hline \multicolumn{2}{|c|}{$\begin{array}{c}\text { FAME content } \\
{[\%(V / V)]}\end{array}$} & $\begin{array}{c}\text { Expanded uncertainty of } \\
\text { the determination result }\end{array}$ \\
$\mathrm{U}(\mathrm{R})=2 \cdot \mathrm{R} / 2.8 \%(V / V)$ \\
$\begin{array}{c}\text { expected (based on } \\
\text { the weight prepara- } \\
\text { tion of the model } \\
\text { blend) }\end{array}$ & $\begin{array}{c}\text { determined } \\
\text { according to } \\
\text { PN-EN 14078 }\end{array}$ & \\
\hline 3.0 & 3.1 & 0.1 \\
\hline 7.0 & 7.4 & 0.4 \\
\hline 15.1 & 15.8 & 0.9 \\
\hline 19.8 & 20.6 & 1.1 \\
\hline 30.1 & 31.2 & 1.4 \\
\hline
\end{tabular}




\section{The analysis of samples containing FAMEs derived from soybean, coconut and palm vegetable oils}

In order to confirm the obtained results of tests of model FAME blends, the later phase of the work did not use blends made from individual esters but rather commercial FAME made from soybean and palm oils. The coconut oil FAMEs were produced in laboratory conditions in accordance with PN-EN ISO 5509 [19].

Solutions of the FAMEs with appropriate concentrations in the base diesel fuel were prepared and FAME content measurements were performed according to PN-EN 14078:2014 [18]. The obtained analytical results are presented in Tables 6,7 and 8.

The analysis of the obtained results showed that, like in the case of the use of blends of individual FAMEs produced from various fatty acids, the results of the determinations for FAMEs of soybean and palm oils using the calibration curve prepared for FAMEs of rapeseed oil do not differ by more than the expanded uncertainty of the method in relation to the expected value. In case of the results of the FAME tests performed

Table 6. Determination of FAME content according to PN-EN 14078:14 [18] for samples containing soybean oil FAME

\begin{tabular}{|c|c|c|}
\hline \multicolumn{2}{|c|}{$\begin{array}{c}\text { FAME content } \\
{[\%(V / V)]}\end{array}$} & $\begin{array}{c}\text { Expanded uncertainty of } \\
\text { the determination result }\end{array}$ \\
$\begin{array}{c}\text { expected (based on } \\
\text { the weight prepara- } \\
\text { tion of the model } \\
\text { blend) }\end{array}$ & $\begin{array}{c}\text { determined } \\
\text { according to } \\
\text { PN-EN 14078 }\end{array}$ & $\mathrm{U} \cdot \mathrm{R} / 2.8 \%(V / V)$ \\
\hline 2.8 & 2.9 & 0.1 \\
\hline 6.9 & 7.0 & 0.4 \\
\hline 15.1 & 15.3 & 0.9 \\
\hline 19.8 & 20.0 & 1.1 \\
\hline 30.3 & 30.6 & 1.4 \\
\hline
\end{tabular}

for coconut oil, the measurement results were unsatisfactory, though. They were inflated in relation to the expected value by approx. $30 \%$.

Table 7. Determination of FAME content according to PN-EN 14078:14 [18] for samples containing palm oil FAME

\begin{tabular}{|c|c|c|}
\hline \multicolumn{2}{|c|}{$\begin{array}{c}\text { FAME content } \\
{[\%(V / V)]}\end{array}$} & Expanded uncertainty of \\
the determination result \\
$\begin{array}{c}\text { expected (based on } \\
\text { the weight prepara- } \\
\text { tion of the model } \\
\text { blend) }\end{array}$ & $\begin{array}{c}\text { determined } \\
\text { according to } \\
\text { PN-EN 14078 }\end{array}$ & U $/ 2.8 \%(V / V)$ \\
\hline 3.0 & 3.1 & 0.1 \\
\hline 6.9 & 7.2 & 0.4 \\
\hline 15.2 & 15.8 & 0.9 \\
\hline 21.2 & 22.0 & 1.0 \\
\hline 30.0 & 31.2 & 1.4 \\
\hline
\end{tabular}

Table 8. Determination of FAME content according to PN-EN 14078:14 [18] for samples containing coconut oil FAME

\begin{tabular}{|c|c|c|}
\hline \multicolumn{2}{|c|}{$\begin{array}{c}\text { FAME content } \\
{[\%(V / V)]}\end{array}$} & $\begin{array}{c}\text { Expanded uncertainty of } \\
\text { the determination result }\end{array}$ \\
$\mathrm{y}(\mathrm{R})=2 \cdot \mathrm{R} / 2.8 \%(V / V)$ \\
$\begin{array}{c}\text { expected (based on } \\
\text { the weight prepara- } \\
\text { tion of the model } \\
\text { blend) }\end{array}$ & $\begin{array}{c}\text { determined } \\
\text { according to } \\
\text { PN-EN 14078 }\end{array}$ & \\
\hline 3.0 & 4.1 & 0.2 \\
\hline 6.9 & 9.4 & 0.5 \\
\hline 14.6 & 19.9 & 1.1 \\
\hline 20.9 & 27.0 & 1.2 \\
\hline 29.3 & 39.8 & 1.8 \\
\hline
\end{tabular}

The preparation of the calibration curve to determine the FAME content of coconut oil

The conducted tests clearly confirm the necessity to perform instrument calibration using the appropriate FAME when testing samples containing FAME with shorter hydrocarbon chains. Where the FAME content of coconut oil is determined, the preparation of a calibration curve should improve the consistency of the expected value with the measurement result. For this reason, a calibration curve was prepared using FAME of coconut oil composed of individual model fatty acid esters shown in Table 2. Figure 1 shows the resulting curve compared to the corresponding curve obtained for rapeseed oil FAME. Then, the FAME content was read again on the basis of the newly prepared calibration curve. The obtained results are presented in Table 9.

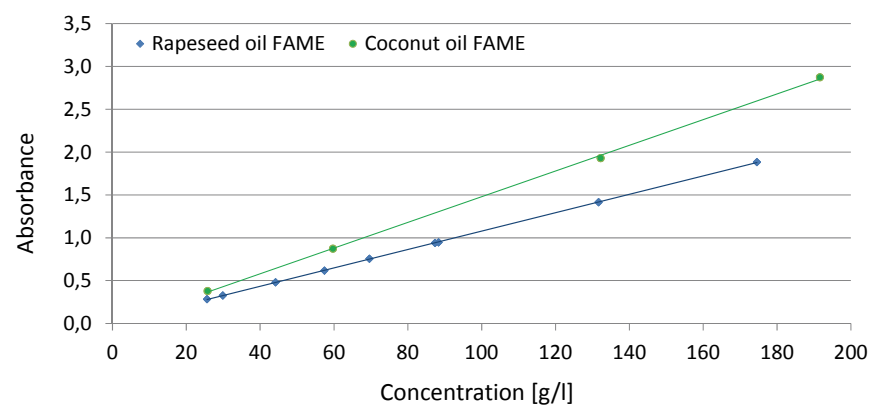

Fig. 1. Comparison of the calibration curves prepared using FAMEs of rapeseed oil and coconut oil

In this case, the expected and obtained values are within the value of the expanded uncertainty of measurement. 
Table 9. The determination of FAME content according to PN-EN 14078:14 [18] for samples containing coconut oil

FAME (coconut oil FAME calibration)

\begin{tabular}{|c|c|c|}
\hline \multicolumn{2}{|c|}{$\begin{array}{c}\text { FAME content } \\
{[\%(V / V)]}\end{array}$} & $\begin{array}{c}\text { Expanded uncertainty of } \\
\text { the determination result }\end{array}$ \\
$\mathrm{y}(\mathrm{R})=2 \cdot \mathrm{R} / 2.8 \%(V / V)$ \\
$\begin{array}{c}\text { expected (based on } \\
\text { the weight prepara- } \\
\text { tion of the model } \\
\text { blend) }\end{array}$ & $\begin{array}{c}\text { determined } \\
\text { according to } \\
\text { PN-EN 14078 }\end{array}$ & \\
\hline 3.0 & 3.1 & 0.2 \\
\hline 6.9 & 6.9 & 0.5 \\
\hline 14.6 & 14.4 & 1.1 \\
\hline 20.9 & 20.6 & 1.2 \\
\hline
\end{tabular}

\section{Conclusions}

1. The use of FAMEs of soybean and palm oils as a diesel fuel biocomponent, instead of FAMEs of rapeseed oil, does not significantly affect the correctness of FAME content determination tests according to PN-EN 14078 in the case of the preparation of a calibration curve for the method using one of the FAMEs mentioned above.

2. In the case of the use of the FAME derived from coconut oil as a diesel fuel component, the results of the determination of this component can be inflated by up to $30 \%$ in the case of the use of a calibration curve prepared using the FAME of rapeseed oil for the measurement.

3 . If the case a FAME determination result was obtained according to PN-EN 14078 [18] and exceeded the value permitted by the Regulation [16] for the diesel fuel sample, one should take into account the possibility that FAMEs with shorter hydrocarbon chains, which can potentially cause an inflation of the obtained results. In order to confirm or disprove this, the FAME content should be reread on the basis of a calibration curve prepared for the FAME corresponding to the esters present in the analysed fuel sample. However, in order to correctly assess the nature of the FAMEs used, it is necessary to perform additional tests, such as chromatographic tests. Such tests do not fall within the scope of the obligatory quality tests for diesel fuel containing FAME.

4. A laboratory should be prepared for the possibility of the occurrence of samples containing FAMEs with shorter chains than the FAMEs of rapeseed oil and be able to calibrate the instrument with the appropriate FAME.

Please cite as: Nafta-Gaz 2018, no. 8, pp. 613-618, DOI: 10.18668/NG.2018.08.07

Article contributed to the Editor 15.12.2017. Approved for publication 20.07.2018.

The article was written on the basis of the statutory study entitled: Zastosowanie FAME z różnych olejów roślinnych a prawidłowa ocena ich zawartości [The use of FAME from different vegetable oils and the correct assessment of their content] - an INiG - PIB study commissioned by the Ministry of Science and Higher Education; archival number: DK-4100-92/17, order number: 0105/TA/17.

\section{Literature}

[1] Baranik M, Łaczek T.: Właściwości niskotemperaturowe biopaliw zawierajacych estry metylowe kwasów tluszczowych pochodzących z przeróbki tłuszczów zwierzęcych. Nafta-Gaz 2010, no. 11, pp. 1047-1058.

[2] Burnus Z.: Badania jakościowe paliw oxydiesel technika chromatografii gazowej z systemem detekcji (O-FID). Nafta-Gaz 2010, no. 9, pp. 849-857.

[3] Burnus Z.: Nowa metoda oznaczania sumarycznej zawartości estrów metylowych kwasów tluszczowych. Nafta-Gaz 2011, no. 7, pp. 502-511.

[4] Burnus Z.: Oznaczanie wolnych steroli roślinnych i zwierzęcych w estrach metylowych kwasów tluszczowych z wykorzystaniem techniki chromatografii gazowej. Nafta-Gaz 2013, no. 8, pp. 632-645.

[5] Hee Kay K., Md Yasir S., Kudumpor K.: Development of Fast
Check Test Kit for Biodiesel Quality Monitoring. International Journal of Chemical Engineering and Applications 2012, vol. 3, no. 5, pp. 307-310.

[6] McCurry J. Wang Ch.: Analysis of Fatty Acid Methyl Ester (FAME) Content and Distribution in Biodiesel Blends Using Heart-Cutting 2D Gas Chromatography. https://www.agilent. com/cs/library/applications/5989-8107EN.pdf (access: October 2017).

[7] Montoya C., Cochard B., Flori A., Cros D., Cuellar T., Espeout T., Syaputra I., Villeneuve P., Pina M., Ritter E., Leroy T., Billotte N.: Genetic Architecture of Palm Oil Fatty Acid Composition in Cultivated Oil Palm (Elaeis guineensis Jacq.) Compared to Its Wild Relative E. oleifera (H.B.K) Cortés. $9^{\text {th }}$ May 2014; http://journals.plos.org/plosone/article?id=10.1371/ journal.pone.0095412 (access: October 2017). 
[8] Norton G.A., Cline M. A., Thompson G.C.: Use of radiocarbon analyses for determining levels of biodiesel in fuel blends Comparison with ASTM Method D7371 for FAME. Fuel 2012, vol. 96, pp. 284-290.

[9] Rintoul S.: Infrared Analysis: Providing reliable \& accurate biodiesel blend measurements. $20^{\text {th }}$ May 2012; http://www. nacleanenergy.com/articles/13084/infrared-analysis-providing-reliable-accurate-biodiesel-blend-measurements (access: October 2017).

[10] Shimamoto G.G., Bianchessi L.F., Tubino M.: Alternative metod to quantify biodiesel and vegetable oil In diesel-biodiesel blends through ${ }^{1} H$ NMR spectroscopy. Talanta 2017, vol. 168, pp. 121-125.

[11] Shimamoto G.G., Tubino M.: Alternative methods to quantify biodiesel in standard diesel-biodiesel blends and samples adulterated with vegetable oil through UV-Visible spectroscopy. Fuel 2016, vol. 186, pp. 199-203.

[12] Sitko R., Zawisza B., Kowalewska Z., Kocot K., Polwniak M.: Fast and Simple method for determination of fatty acid metyl esters (FAME) In biodiesel blends Rushing X-ray spectrometry. Talanta 2011, vol. 85, pp. 2000-2006.

[13] Website: http://solvadis.pl/biopaliwa-i-oleje/ (access as of 30.10.2017).

[14] Website: https://www.chempro.in/fattyacid.htm (access as of 30.10.2017).

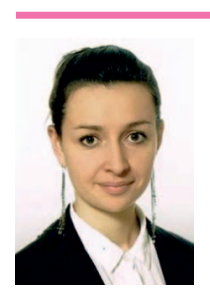

Dagmara NOWAK M.Sc., Eng.

Engineering and technical specialist at the Department of Oil Analyzes

Oil and Gas Institute - National Research Institute

ul. Lubicz 25A

30-507 Krakow

E-mail: dagmara.nowak@inig.pl

\section{Legal and normative acts}

[15] Announcement of the Minister of Energy of 18 January 2017 on announcing the uniform text of the Regulation of the Minister of Economy on methods of testing the quality of liquid fuels (Dz.U. 2017, item 247).

[16] Regulation of the Minister of Economy of 9 October 2015 on quality requirements for liquid fuels (Dz.U. 2015, item 1680).

[17] Standard ASTM D 7371-14 Standard Test Method for Determination of Biodiesel (Fatty Acid Methyl Esters) Content in Diesel Fuel Oil Using Mid Infrared Spectroscopy (FTIR-ATRPLS Method).

[18] Standard PN-EN 14078:2014 Liquid petroleum products. Determination of fatty acid methyl ester (FAME) content in middle distillates. Infrared spectrometry method.

[19] Standard PN-EN ISO 5509:2001 Animal and vegetable fats and oils. Preparation of methyl esters of fatty acids.

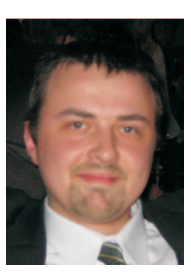

Aleksander KOPYDŁOWSKI M.Sc., Eng. Engineering and technical specialist at the Department of Oil Analyzes. Oil and Gas Institute - National Research Institute ul. Lubicz 25A 31-503 Krakow E-mail: kopydlowski@inig.pl

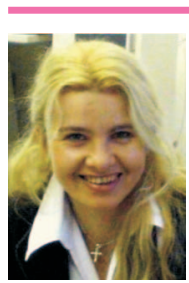

Agnieszka WIECZOREK M.Sc., Eng. Research and technical specialist at the Departmen of Oil Analyzes, Head of the Instrumental Analysis Laboratory.

Oil and Gas Institute - National Research Institute ul. Lubicz 25A, 31-503 Krakow E-mail:agnieszka.wieczorek@inig.pl 